DOI https://doi.org/10.18551/rjoas.2018-07.11

\title{
IMPULSIVE AND COMPULSIVE BUYING IN RETAIL BUSINESS: AN OVERVIEW OF CONSUMER BEHAVIOR IN INDONESIA
}

\author{
Zakiatuzzahrah*, Doctoral Candidate \\ Business Administration, University of Padjadjaran, Indonesia \\ Arifianti Ria, Muftiadi Anang, Alexandri Mohammad Benny \\ Business Administration Department, University of Padjadjaran, Indonesia \\ *E-mail: zakiayenny@yahoo.com
}

\begin{abstract}
The presence of pick-up service has caused a shifting in the pattern of consumer behavior. This happens particularly in the retail sector so that the growth of this business is increased. This paper aims to explain the relationship between impulsive and compulsive buying behavior in the retail sector. Previous studies showed that product characteristics and purchasing behavior of the retail sector are strongly related to the impulsive and compulsive buying behavior. The shifting model of conventional to online retail business demands retail management to design various strategies. One of which is to develop a creative retail mix. As a response to the trend of online retail, the management must redefine the understanding of such retail mix so as to develop a retail mix based on information technology.
\end{abstract}

\section{KEY WORDS}

Retail mix, impulsive buying, compulsive buying, business.

In order to understand consumer behavior comprehensively, there are several terms that must be discussed beforehand such as (i) the external and internal factors that influence buying decisions. The external factors are cultural (culture, sub-culture, and social class), social (household type, reference group role, and status), and environmental (environment, economic, and technology). On the other and, the internal factors include psychological (motivation, perception, learning, belief, attitude, self-concept, and personality), personal (age, lifestyle, occupation, education, and economic situation); Marketing program (marketing mix, retail mix); (ii). The buying process and decision (in which there is a discussion of impulsive and compulsive buying); (iii). Post-purchase behavior which is a subject that must be understood deeply and thoroughly (Parasuraman, et.al, 2002; Solomon, 2010; Priest, et al., 2013; Ramya \& Ali, 2016).

Other than that, the 4.0 industry that is based on digital technology has been influential on consumer behavior including Indonesia. The presence of information technology makes consumers prefer buying through the online platform. The increase in online buying behavior which is due to the availability of pick-up service, particularly in the retail sector, makes the retailers change their business model. One of which is by closing the conventional outlets and investing it in the online models. This strategy is chosen by Seven Eleven (SeVel), Lotus and Debenhams, and some national retailers such as Matahari and Ramayana. All of those retailers migrate to the online business model by partially reducing or closing their conventional outlets. This is a form of response to the shifting of consumer behavior.

The fall of conventional retail is due to the changes in lifestyles which most of the Indonesian people consider traveling and leisure more important. The shifting in lifestyles is also due to the increasing number of middle-class population and the rise in incomes in recent years. According to the data released by the Central Bureau of Statistics (2017), Indonesia's middle class has increased to 8-9 million people per year. Thus, it can be said that Indonesia's middle-class population has touched the number of about 130 million people. The condition is reinforced by the GDP per capita of Indonesian society that is the US $\$ 3000$. 
Broadly speaking, various macro environmental conditions in Indonesia have good conditions. This condition, which is due to the improving consolidation of democracy (politics) in Indonesia, has such indirect positive impact on the other dimensions of life, especially in the social, demographic, and economic aspects. Seen from the social and demographic state, some macro indicators show a pleasing condition. It is known that the Gini Ratio becomes smaller, the middle class is getting bigger, and the productive age is greater because of this demographic condition. In addition, the improved information technology infrastructure and improved inter-regional connectivity along with the development of various physical infrastructures such as airports, roads, ports, and other physical infrastructures make a distinct influence for some communities in their roles as a consumer.

Indonesia's macroeconomic indicator also represents a good condition. Even though the realization of 2018 economic growth is estimated to miss the target or only grew by $5.05 \%$ of the target set at $5.2 \%$, the macroeconomic condition shows a better state than the global condition. In addition to that, people's consumption also growing better along with the low inflation. Consumer price inflation (CPI) in 2017 was the lowest in history reaching up to $3.18 \%$. Those two indicators above give an idea that the consumption rate of Indonesian people today has a promising figure (BPS, 2018).

After the external environment condition that potentially influences consumer behavior (especially retail sector) is discussed in macro, hereinafter will discuss the potential impulsive and compulsive buying amidst the increasingly shifting behavior of buying (online). The topic of impulsive and compulsive buying behavior becomes increasingly important and interesting to be brought into the study since these two purchasing behaviors dominate the retail sector. This will be discussed without having to dispel the debate about ethics that is related to strategy advice, especially compulsive buying. (Muruganantham \& Bhakat, 2013; Obaga, et.al, 2013; Vishnu \& Raheem, 2013; Zaman \& Zaman, 2014; Moon, et al, 2015).

Impulsive and Compulsive Buying in Retail Sector. Despite the variety of definitions of retail business, researchers agree that retail is essentially a business activity that sells products or services focusing on its use for personal and household consumption and not for business purposes. The differences in the size or volume of business are generally used as the basis for the classification of retail types. One of which is Kotler \& Armstrong (2015) who classifies retail business based on the size, starting from department stores, supermarkets, and hypermarket.

Furthermore, Kotler \& Armstrong (2015) asserted that although there are some differences in retail type, the products or services are generally the same. As for examples, the daily necessities category including toothpaste, milk, snacks, magazines, newspapers, detergents, clothes, and other types of products. There is also a category of shopping which generally in the form of large furniture, television, and other products. In general, the products sold in retail have a relatively low price. The distribution of products is widespread and easily accessible with a mass promotion system. In most cases, the consumers have a low engagement in the transaction and such impulsive buying is generally more dominant in the retail sector.

The study of impulsive buying has been the concern of researchers for a long time. (Clover, 1950; Stern, 1962; Rook, 1987; Peck and Childers; 2006; Chang et al., 2011; Banerjee \& Saha, 2012; Setyningrum, et.al, 2016). Among the various studies above, impulsive buying usually occurs when a consumer strolling around to a place where all needs and desires are available such as in a shopping center. Impulsive buying is a shopping behavior which occurs unplanned when making spontaneous decisions. It does not matter whether a consumer is in a pure impulse buying condition (deviating from normal purchases) or in a suggestion impulse buying (where a new consumer first sees the product by looking at the quality, function, and usefulness of product as expected.

This is similar to compulsive buying. However, this behavior exhibits something that tends to be negative (to make purchases beyond the ability to buy simply because of selfesteem (materialistic consideration), as a form of anxiety and others expressions that nuanced "negative" state. In general, the retail sector is the ultimate choice for an individual to do a compulsive buying. Besides that, the dominant factors that significantly affect the 
compulsive buying behavior are the openness to experience, thoroughness, extraversion, friendliness, and neuroticism (Bozionelos, 2004; Lin, 2010; Tommasel et.al., 2015; Ergin, 2010; Khare, 2013; Gupta, 2013; Bighiu, et al, 2015).

As a response to the dynamic factors that affect consumer behavior especially the buying behavior in the retail sector that is generally dominated by compulsive and impulsive buying behavior, a creativity of retailers in designing strategies is needed. To adapt to the existing dynamics, one of the creativities that need to be developed is to design a retail marketing mix that can answer the dynamics of the environment above.

Developing Retail Mix. The retail industry is a fairly homogeneous industry at which products sold between retailers are almost the same. However, behind this homogeneity, there is an interesting thing to be observed. In facing the increasingly competitive retail business, various different and interesting alternatives should be done by the retailers so that consumers will make the store as an option to shop. One strategy that is considered able to win the competition is to develop the strategy of retail mix marketing. (Lazer, 1961; Gauri, et.al, 2008; Balasescu, 2014; Azeem \& Sharma, 2015; Terblanche, 2017).

The retail mix is a strategy that combines the four elements of marketing, namely place, price, product, and promotion. Physical facility and service are then combined to produce the expected feedback. Each element of this strategy is optimized to make the store superior in competing with other retailers. One of the researchers, who focus on retail mix marketing is Berman \&. Evans (2011). They developed a retail mix marketing which consists of product, price, promotion, as well as service and facility/location.

Along with the shifting of conventional stores to online shops, the explanations of each retail mix definition needs to be adjusted. Other than that, the addition of retail mix marketing elements is very possible when starting a new e-business (Kalyanam \& Shelby, 2002). For example, the location of the store (in the physical sense) should be interpreted as a form of website where consumers "visit" the web. Therefore, it should be designed as a user-friendly website with common characteristics such as the clear identity of the website, good devices, fast loading time, intuitive navigation, compelling content, easy-to-read text, fun element of experience, clear rules, and guaranteed visitor privacy.

Products are a very important element in retail business. The availability of products is very important for the retail industry because customers are always looking forward to meet what is needed and desired in every store. The needs and desires of customers are very diverse in which the store is expected to fulfill it. The function of product managers (procurement and availability) is important. If the availability of the products is problematic, the competitive advantage of the retail sector will almost certainly be difficult to get (Balasescu, 2014). Meanwhile, the online retail model requires the management to display the products on the web either through photos or videos, so that visitors will be satisfied with the information about the products. (Senecal \& Jacques, 2004; John \& Anand, 2012; Riquelme, et.al, 2016)

Price is also a very important aspect for retailers. The success of the business is also largely determined by the pricing strategy. The management must be able to set the right price for the goods so that the sale will be more secure. Even though it is difficult to realize, all retailers try to set a high price with a high volume of sale in general. The pricing is in regard to many aspects related to profit maximization, customers' perceptual and psychological condition, market response, goods availability, image and product quality, brand perception, as well as laws and regulations. (Basuroy, et.al, 2001; Khare, 2014).

Communication also plays an important role in the success of the retail business. Communication, which is in the form of promotion, is basically one aspect that aims to drive the target market to be willing to become buyers and customers. The essence of this promotion is the way we deliver what we offer to the consumer to be well received. Marketing communication not only able to make customers interested in buying, but also to create a specific image adapted to the target market. The mix of promotion generally consists of advertising, sales promotion, personal selling, public relations, and direct marketing. (Grewal, et.al, 2011; Shamout, 2016) 
The presence of information technology especially social media makes this retail mix has its own challenges because it requires creativity. The increasing channels (Facebook, Instagram, Twitter, etc.) and the diverse forms of promotion (story-telling, video blogger, etc.) require the practitioners in the field of promotion to understand the characteristics of online buyers better. Integrating marketing communication by using conventional and online media makes mix promotion as one of the keys to success in the retail field. (Favero \& Alvares, 2013; Mapheto, et.al, 2014; Ots \& Nyilasy, 2017).

Service has an increasingly noticeable role. A service is essentially intangible and does not cause a possession of anything. However, a service can basically be included in a physical product. Such service, in general, is serving the customers right before shopping, while shopping, and even after shopping. Service is an aspect which has an important role in the competition. It becomes real for the company to compete with the competitors because the element of service is very difficult to be imitated by others. (Bitner, et al, 1994). Kotler (2015) divided service into two parts. First, primary service which consists of credit payments, delivery, complaint handling, park handling, restroom, and toilet. Secondly, secondary service which includes packaging, products location information, consultation and purchase information, as well as deposit box.

When the purchasing behavior has not shifted into online buying, physical facility is a decisive factor in shaping the dominant market share desired by the company. Therefore, adjustments are needed along with this shifting. Physical facilities must be interpreted also with a web display that is easy to understand and is supported by various other facilities. Specifically, physical facilities (conventional retail) must meet several important elements that can be highlighted such as the image of the store in the form of good architecture, attractive exterior and interior design, adequate human resources, and a good supply of goods.

Moreover, a strategic location should be taken into account. The flow of consumer traffic in the area should be considered whether it can be a business center or not. The flow of consumer traffic will affect the placement of the retail stores because location can attract consumers and affect the impulsive and compulsive buying. (Bloemer \& Ruyter, 1998; Jaravaza \& Chitando, 2013; Sun \& Rashad, 2015).

Conclusion. The product characteristics and buying behavior in the retail sector are highly relevant to the characteristics of impulsive and compulsive buying behavior. It is known that the shifting of buying behavior is due to a large number of pick-up services. This has made the retailers to adjust their business strategies and models. One thing that needs to be done is to change the understanding of retail mix marketing. This is considered substantial in the middle of the trend in which retailers choose to be market-driven organization.

\section{REFERENCES}

1. Azeem, S \& Sharma. (2015). Elements of the retail marketing mix: a study of different retail formats in India. The Business \& Management Review, Vol. 5(4), pp. 51-61.

2. Balasescu, S. (2014). Contributions to the Foundation of the Marketing Mix for Retail Companies. Bulletin of the Transilvania. University of Brasov. Series V: Economic Science. Vol.7 (56), pp.78-85.

3. Banerjee, SA \& Sunetra S.(2012). Impulse Buying Behaviour in Retail Stores: Triggering Senses. Asia Pacific Journal of Marketing \& Management Review. Vol. 1(2), pp. 56-68.

4. Basuroy, S., Allen, BJ \& Chandrasekaran D. (2001). The Impact of Category Management on Retailer Prices and Performance: Theory and Evidence. Journal of Marketing. Vol. 65(7), pp.16-32.

5. Berman, B \& Evans, JR. (2011). Retail Management: Strategic Approach. Upper saddle River: Pretice Hall International. Inc.

6. Bitner, MJ, Booms, BH \& Mohr, LA. (1994). Critical service encounters: the employee's viewpoint. Journal of Marketing. Vol. 58(4): 95-106.

7. Bozionelos, N. (2004). The big five of personality and work involvement. Journal of Managerial Psychology. Vol. 19(1), pp.69-81. 
8. Bighiu, G., Monalica, A., \& Roman, CT. (2015). Compulsive buying behavior on the Internet. Prodia Economic and Finance. Vol. 20, pp.72-79.

9. Bloemer, J, \& de Ruyter, K. (1998). On the relationship between store image, store satisfaction and store loyalty. European Journal of Marketing, 32(5/6). pp. 499-513.

10. Brocato, ED, Voorhees, CM., \& Baker, J. (2012). Understanding the influence of cues from other customers in the service experience: A scale development and validation. Journal of Retailing. 88(3). pp. 384-398.

11. Clover, VT. (1950). Relative Importance of Impulse-buying in retail stores. The Journal of Marketing, Vol. 15(1), pp. 66-70.

12. Chang, HJ., Eckman, M., \& Yan, RN. (2011). Application of the Stimulus Organism Response model to the retail environment: the role of hedonic motivation in impulse buying behavior. The International Review of Retail, Distribution and Consumer Research, 21(3).p.233-249.

13. Ergin, EA. (2010).Compulsive buying behavior tendencies: The Case of Turkish Consumers. African Journal of Business Management. Vol. 4 (3). pp. 333-338.

14. Favero, MB \& Alvares, FJSM. (2013). Integrated Communication in Retail: A Study of Integration between Advertising and Communication at the Point of Sale. Journal of Art and Humanities. Vol. 2(2), pp. 25-37.

15. Gauri, DK. 2008. Understanding the Determinants of Retail Strategy: An Empirical Analysis. From http://www.dhruvgrewal.com/wp-content/uploads/2014/09/2008-JR-RetailStrategy-Format.pdf on July 6th, 2018.

16. Gupta, S. (2013). A Literature Review of Compulsive Buying-A Marketing Perspective. Journal of Applied Business and Economic. Vol. 14(1), pp. 43-48.

17. Grewal, D. (2011). Innovations in Retail Pricing and Promotions. Journal of Retailing. Vol. 87(2).p.43-52.

18. Jaravaza, DC \& Chitando, P. (2013). The Role of Store Location in Influencing Customerrs" Store Choice. Journal Of Emerging Trends In Economics and Management Sciences. Vol 4.(3).p.302-307.

19. John, F \& Christopher A. (2012). A Study on Factors Affecting Sales of Branded Product in Retail Sector. A Study on Factors Affecting Sales of Branded Product in Retail Sector. Vol. 2(9), pp.1-5.

20. Kalyanam, K \& McIntyre, S. (2002). The E-Marketing Mix: A Contribution of the E-Tailing Wars. Journal of the Academy of Marketing Science. Vol. 30(4), pp. 483-495.

21. Kottler, P \& Amstrong, G. (2015). Principles of Marketing. Tenth Edition, New Jersey. Pearson Pretice Hall.

22. Khare, A. (2013). Credit Card Use and Compulsive Buying Behavior. Journal of Global Marketing. Vol. 26(7), pp. 28-40.

23. Khare, A. (2014). Influence of Price Perception and Shopping Motives on Indian Consumers' attitude towards retailer promotions in malls. Asia Pacific Journal of Marketing and Logistic. Vol. 26(2), pp. 272-295.

24. Lazer, W \& Kelly. (1961). The retailing mix: planning and management. Journal of Retailing. Retrieved from:https://scholar.google.co.id/, on July 7th, 2018

25. Lin, L. (2010). The relationship of consumer personality trait, brand personality and brand loyalty: an empirical study of toys and video games buyers. Journal of Product \& Brand Management. Vol. 19(1), pp. 4-17.

26. Mapheto, L., Olabanji, M., Oni, A \& Matiza, T. (2014). The Utilisation of Integrated Marketing Communication Strategies by Small Retailers in Mankweng, South Africa. Mediteranean Journal of Social Science. Vol. 5(15), pp. 7-16.

27. Moon, MA, Rasool, H \& Attiq, S. (2015). Analysis of Compulsive Buying Behavior: Questioning the Role of Marketing Campaigns. From: https://www.researchgate.net/ on July 7 th, 2018

28. Muruganantham, G \& Ravi SB. (2013). A Review of Impulse Buying Behaviour. From: 29. http://www.ccsenet.org/journal/index.php/ijms/article/view/24570. on July 3th, 2018 
30. Parasuraman, A, Baker, J, Grewal, D, \& Voss, GB. (2002). The influence of multiple store environment cues on perceived merchandise value and patronage intentions. From. http://journals.ama.org/ on July 7th 2018.

31. Ots, M \& Nyilasy, G. (2017). Just doing it: Theorizing Integrated Marketing Communications (IMC) Practices. European Journal of Marketing. Vol. 51(3).p. 490-510.

32. Obaga, IM. (2013). Analysis of retail marketing strategies on Organizational Competitiveness. International Journal of Management \& Information Technology. Vol. 3(2), pp. 43-46.

33. Priest, J, Carter S \& Statt, DA. (2013).Consumer Behaviour. Edinburgh Business School. United Kingdom.

34. Peck, J \& Childers, TL. (2006). If I touch it I have to have it: individual and environmental influences on impulse purchasing. Journal of Business Research. Vol. 59(6). p.765-769

35. Ramya, N \& Ali, M. (2016). Factors Affecting Buying Behavior. International Journal of Applied Research. Vol. 2(10), pp. 76-80.

36. Riquelme, IP, Roman S \& lacobucci D. (2016). Consumers' Perceptions of Online and Offline Retailer Deception: A Moderated Mediation Analysis. Retrieved from. https://www.researchgate.net/ on July 7th 2018.

37. Rook, DW. (1987). Buying Impulse. From: https://academic.oup.com/, on July 7th 2018.

38. Senecal S \& Nantel J. (2004). The Influence of online product recommendations on consumers' online choice. Journal of Retailing. Vol. 80(7), pp. 159-169.

39. Setyningrum, FY, Arifin Z \& Yulianto E. (2016). Pengaruh Hedonic Motives Terhadap Shopping Lifestyle dan Impulse Buying: Survei pada Konsumen Superindo Supermarket Yang melakukan Impulse Buying. Jurnal Administrasi Bisnis (JAB). Vol. 37, pp. 45-55.

40. Shamout \& Dawood M. (2016). The Impact of Promotional Tools on Consumers Buying Behavior in Retail Market. International Journal of Business and Social Science. Vol. 7(1), pp. 75-85.

41. Stern, H. (1962). The Significance of Impulse Buying Today. From https://www.jstor.org/stable/1248439 on July 7th 2018.

42. Solomon, MR, Bamossy, G, Askergaard, S \& Hogg, MK. 2010. Consumer Behaviour: European Perspective. 4th Essex: Prentice Hall.

43. Sun, TR \& Yazazdanifard. (2015). The Review of Physical Store Factors That Influence Impulsive Buying Behavior. International Journal of Management Accounting and Economic. Vol. 2(9), pp. 1048-1054.

44. Terblanche, NS. (2017). Customer Interaction with Controlled retail Mix elements and their relationship with customer loyality in diverse retail environment. Journal of Business and Retail Management Research. Vol 11(2), pp.1-9.

45. Tommasel, A, Corbellini, A, Godoy, D \& Schiaffino, S. (2015). Exploring the role of personality traits in followee recommendation. Online Information Review. Vol. 39(6), pp. 812-830.

46. Vishnu P \& Raheem AR. (2013). Factors Influencing Impulse Buying Behavior. European Journal of Scientific Research. Vol. 100(3), pp. 67-79.

47. Zaman MH \& Zaman M. (2014). Compulsive Buying Behavior in Virtual Worlds: An Exploratory Study. International Journal of Business and Management. Vol. 1(1), pp. 6779. 